\title{
West Florida Shelf pipeline serves as sea turtle benthic habitat based on in situ towed camera observations
}

\author{
Heather A. Broadbent ${ }^{1, *}$, Sarah E. Grasty ${ }^{1}$, Robert F. Hardy ${ }^{2}$, Margaret M. Lamont ${ }^{3}$, \\ Kristen M. Hart ${ }^{4}$, Chad Lembke ${ }^{1}$, Jennifer L. Brizzolara ${ }^{1}$, Steven Murawski ${ }^{1}$ \\ ${ }^{1}$ University of South Florida, College of Marine Science, Saint Petersburg, FL 33701, USA \\ ${ }^{2}$ Florida Fish and Wildlife Conservation Commission, Fish and Wildlife Research Institute, Saint Petersburg, FL 33701, USA \\ ${ }^{3}$ US Geological Survey, Wetland and Aquatic Research Center, Gainesville, FL 32653, USA \\ ${ }^{4}$ US Geological Survey, Wetland and Aquatic Research Center, Davie, FL 33314, USA
}

\begin{abstract}
The use of marine offshore benthic habitats by sea turtles is poorly characterized due to the difficulty of obtaining in situ data. Understanding benthic habitat use that is important to the species' reproduction, foraging, and migrations is critical for guiding management decisions. A towed camera-based assessment survey system (C-BASS) equipped with environmental sensors was used to characterize and assess benthic habitats on the West Florida Shelf (WFS) from 2014 to 2018. During these cruises, sea turtles were opportunistically observed during the surveys, and critical in situ data such as spatiotemporal information, species identification, habitat use, behavior, and environmental data were collected and evaluated. In total, 79 sea turtles were observed during 97 transects of approximately $2700 \mathrm{~km}$ of seafloor, which was recorded on $380 \mathrm{~h}$ of video. Several sea turtle species were spotted within the WFS, including loggerhead Caretta caretta, Kemp's ridley Lepidochelys kempii, and green turtles Chelonia mydas. These opportunistic sightings revealed an area of high use on the WFS, an anthropogenic structure known as the Gulfstream natural gas pipeline (GSPL). C-BASS survey results suggest that 2 sea turtle species (C. caretta and L. kempii) utilize this artificial structure primarily as a resting area. We emphasize the importance of combining habitat mapping techniques (towed underwater video and multibeam bathymetry/backscatter) with tracking technology to better understand the fine-scale habitat use of sea turtles.
\end{abstract}

KEY WORDS: Sea turtles - Benthic habitat use - West Florida Shelf - Towed underwater video · Loggerhead $\cdot$ Kemp's ridley $\cdot$ Artificial reefs $\cdot$ Environmental parameters

\section{INTRODUCTION}

Most sea turtles spend a large portion of their lives underwater associated with distinctive habitats (Lutz et al. 2002). These habitats are crucial to sea turtle survival because they serve as areas of foraging, resting, mating, and refuge from predators (Rosman et al. 1987, Lohoefener et al. 1990, Hart et al. 2014, Barnette 2017). There are several sea turtle species that inhabit the West Florida Shelf (WFS) in the Gulf of

\footnotetext{
*Corresponding author: hbroadbent@mail.usf.edu
}

Mexico (GoM): loggerhead Caretta caretta; green turtle Chelonia mydas; leatherback Dermochelys coriacea; hawksbill Eretmochelys imbricata; and Kemp's ridley Lepidochelys kempii (Lutz et al. 2002). All but the leatherback are associated with benthic habitat features of the WFS as neritic juveniles, sub-adults, and adults (e.g. seagrass, reef, hardbottom; Eaton et al. 2008). All sea turtles found in US waters are listed under the Endangered Species Act (ESA), and are classified as either Threatened or Endangered (Plot-

(C) Broadbent HA, Grasty SE, Hardy RF, Lembke C, Brizzolara JL, Murawski S and, outside the USA, the US Government 2020. Open Access under Creative Commons by Attribution Licence. Use, distribution and reproduction are unrestricted. Authors and original publication must be credited.

Publisher: Inter-Research · www.int-res.com 
kin 1995). Therefore, collecting in situ habitat use data for these sea turtles is beneficial to their conservation and management efforts. Depending on the species, these benthic habitats can include sea grass beds (green turtles; Ballorain et al. 2010), coral reefs (hawksbills; Walcott et al. 2014), natural rocky hard bottoms (loggerheads; Hart et al. 2010), and rock outcroppings (Kemp's ridleys; Schmid et al. 2003). Having a better understanding of how benthic habitats support multiple sea turtle species (both temporally and spatially) is critical for the sustainable management of resources in our oceans. Distribution of sea turtles on the WFS has been associated with water temperature and benthic habitat features (natural and artificial) which aggregate prey (Fanning et al. 1981, Foley et al. 2014, Hardy et al. 2014); however, this information is sparse and challenging to obtain (Stoneburner 1982). There has recently been a considerable emphasis placed upon the importance of habitat mapping (Brown et. al. 2011, Fakiris et al. 2019) and a significant by-product of this research could be an increased amount of data on fine-scale sea turtle habitat use.

Habitat maps classify the environment into biogeographic and aquatic settings that are differentiated by features influencing the distribution of organisms, and by environmental variables such as salinity, tidal zone, and proximity to the coast (FGDC 2012). Within habitat classification systems are 4 underlying components that describe different aspects of the seascape: water column, geoform, substrate, and biotic (FGDC 2012). Understanding how environmental conditions (e.g. temperature, salinity, chlorophyll a [chl a]) affect population dynamics could be important in understanding sea turtle life cycles and enhancing biodiversity conservation measures (Revelles et al. 2008, Lamont \& Fujisaki 2014, ZepedaBorja et al. 2017). Clarifying the relationships between sea turtles and their habitats guides conservation research and management activities by, for example, distinguishing and mitigating associated threats coupled to their habitats and by advising critical habitat designation under the ESA (Hamann et al. 2010, USFWS \& NMFS 2013).

Anthropogenic structures such as artificial reefs are utilized by sea turtles because they provide a structure similar to natural ledges and outcroppings. Sea turtles have been observed near or on these artificial structures resting, seeking refuge (Barnette 2017), foraging, and even self-cleaning (Schofield et al. 2006). According to NOAA, an artificial reef is an anthropogenic structure that may mimic some of the characteristics of a natural reef and can include sub- merged shipwrecks, oil and gas platforms, bridges, lighthouses, and other offshore structures. By area, most artificial reefs in the GoM are oil and gas platforms as well as the pipeline infrastructure that connects them (Froeschke \& Dale 2013). There are approximately 4000 active platforms in the GoM with $1000 \mathrm{~s}$ of $\mathrm{km}$ of pipeline lining the seafloor between them. (https://oceanexplorer.noaa.gov/explorations/ 06mexico/background/oil/media/platform_600.html) Studies have shown that the platforms themselves provide habitat for algae, invertebrates, and reef fish species (Gallaway \& Lewbel 1982, Stanley \& Wilson 1991, Love et al. 1999, Scarborough-Bull et al. 2008, Seaman \& Sprague 2013), and sea turtles have been associated with platform locations (Lohoefener et al. 1990, Gitschlag et al. 1997).

Much progress has been made in the understanding of sea turtle terrestrial habitat requirements (nesting females) and the shallow habitat within inter-nesting areas (Hart et al. 2010, Walcott et al. 2014, Shaver et al. 2017). However, knowledge is limited about sea turtle benthic habitat use in offshore regions. Most of these data are collected using timedepth recorders to infer habitat utilization (Hooker et al. 2007) or satellite telemetry combined with bathymetric or dominant benthic sediment type data to predict benthic habitats (Foley et al. 2014). Hardy et al. (2014) described the post-nesting residence areas of adult female loggerheads by combining satellite telemetry data sets with data from a fishery targeting red grouper Epinephelus morio, a species similar to loggerhead sea turtles in terms of habitat use and prey. They concluded that loggerhead residence areas on the WFS were likely focused on specific benthic habitat features including rocky outcroppings, ledges, and hard bottom patches. The benthic habitats of the WFS are important for sea turtle conservation; however, research to date has been challenged by a lack of detailed benthic habitat information. Studies have shown that satellite-tagged adult female turtles utilize the WFS area where a pipelines is located as foraging grounds (Hart et al. 2012), residency areas (Girard et al. 2009, Hardy et al. 2014) and migratory corridors (Shaver et al. 2016). However, characterization of these underwater pipelines, and details of how turtles use them, is unclear.

The University of South Florida (USF) College of Marine Science Continental Shelf Characterization, Assessment, and Mapping Project (C-SCAMP; www. marine.usf.edu/scamp/) has been developing habitat maps and quantifying reef fish species population dynamics within the eastern GoM WFS. This study utilized video data collected as part of C-SCAMP via 
the towed camera-based assessment survey system (C-BASS; Grasty 2014, Lembke et al. 2017). Collection of imagery and environmental data has been focused on commercially and recreationally important reef communities; fortuitously, numerous sea turtles have been observed during these surveys. Results demonstrate that towed camera technology can offer a novel approach to surveying sea turtles among deep, offshore benthic habitats on the WFS.

\section{MATERIALS AND METHODS}

\subsection{Study area}

This study was conducted in the eastern GoM on the WFS, from offshore of Panama City to Tampa Bay (Fig. 1). Benthic habitat data were collected from 4 natural study areas, which have been identified as important habitat for marine species (Hardy et al. 2014, Locker et al. 2016), and one anthropogenic structure (see Fig. 2):

1. The Florida Middle Grounds (FMG) area encompasses $1500 \mathrm{~km}^{2}$ and its depths range from 25 to $50 \mathrm{~m}$. Major features include a series of natural hard bottom ridges located approximately $180 \mathrm{~km}$ northwest of Tampa Bay (Mallinson et al. 2014).

2. The Elbow (EL) is an area south of the FMG in a depth range of 45-65 m. It possesses a large north- south oriented ridge feature as well as several patches of low-relief hard bottom (Ilich 2018).

3. Madison-Swanson (MS) and Steamboat Lumps (SL) are both marine protected areas (MPAs). MS consists of ridges, pinnacles, and mounds, while SL contains mostly low-relief, unconsolidated sediments, but it does have one larger ledge feature in the northern section of the area as well as significant tracts of red grouper E. morio holes (Grasty et al. 2019).

4. The anthropogenic structure in this study is the Gulfstream natural gas pipeline (GSPL) where 2 sections were surveyed: the first was a $134 \mathrm{~km}$ section from 28.2437 to $27.6763^{\circ} \mathrm{N}$ (30-70 $\mathrm{m}$ depths) and the second was a $58 \mathrm{~km}$ section from 29.14732 to $28.7041^{\circ} \mathrm{N}$ (90-195 $\mathrm{m}$ depths). The pipeline runs $700 \mathrm{~km}$ along the seafloor between Mobile Bay, Alabama and Tampa Bay, Florida. Certain areas were dredged for the placement of the pipe and thus dredged rocks and spoils exist on one or both sides for large sections of its length.

\subsection{Surveys}

During 2014-2018, benthic surveys were conducted using the USF-developed C-BASS, which is a towed instrument equipped with cameras and additional sensors that was designed to collect video and environmental data to a depth of $200 \mathrm{~m}$ for up to $20 \mathrm{~h}$

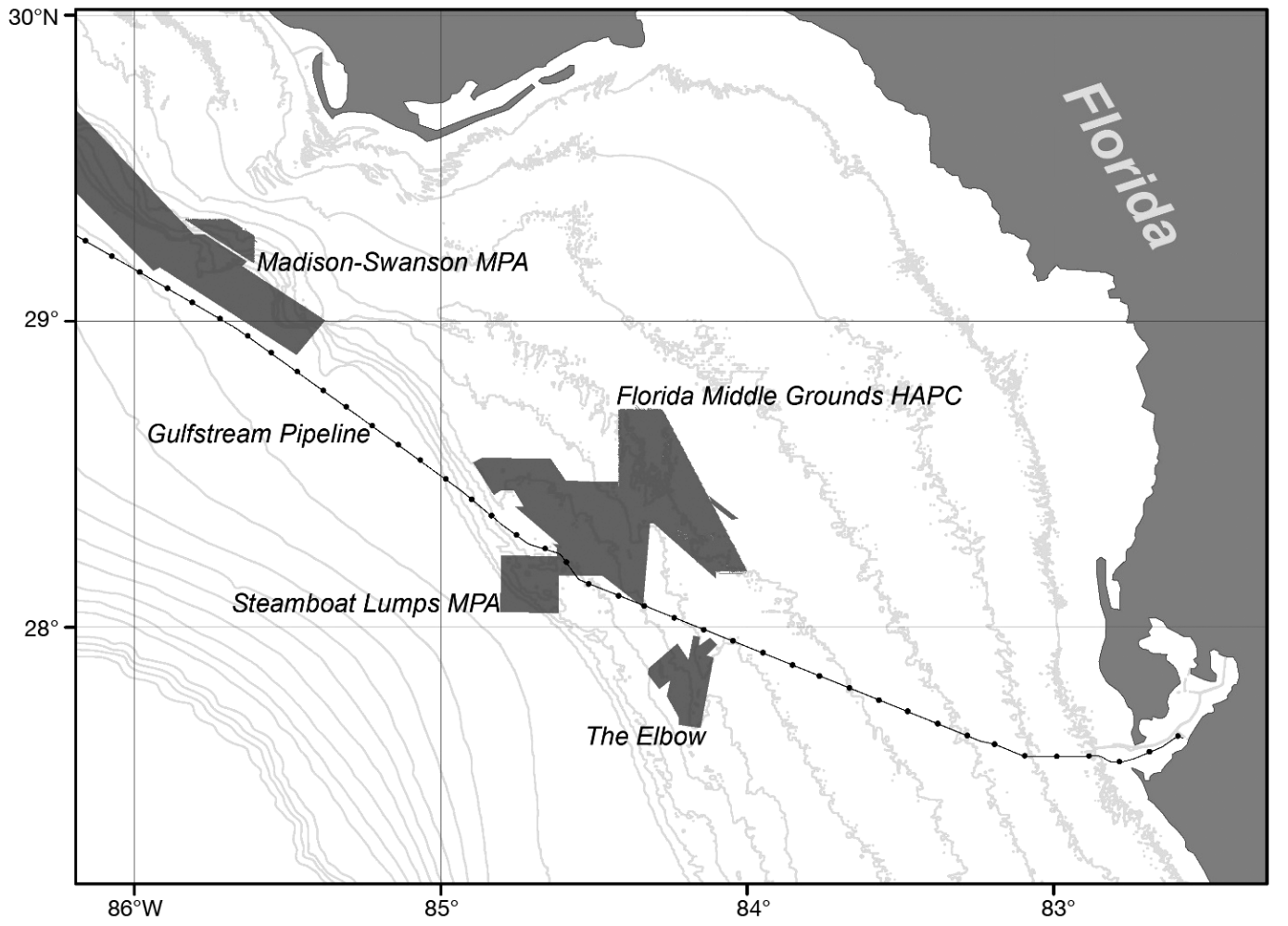

Fig. 1. Overview of the West Florida Shelf where the camera-based assessment survey system (CBASS) transects were completed between 2014 and 2018. Specific area names are indicated for reference. Shaded polygons: extent of the multibeam bathymetry maps that were used to plan the C-BASS transects for ground-truthing purposes 
without surfacing. The C-BASS was configured with 4 LED lights and 6 video cameras; 2 forward facing high-definition (1 black/white and 1 color), and 2 forward-facing and 2 side-facing color standarddefinition cameras. Additional environmental sensors include an RBR XR 420 CTD, a WetLabs FLNTU fluorometer (2014-2016) and a Wetlabs ECO fluorometer (2017-2018), all of which can be monitored in real time.

The C-BASS was deployed off the stern of the R/V 'Weatherbird II' (operated by the Florida Institute of Oceanography, FIO) using the A-frame and winch. Once in the water, the system was powered on and then lowered to the optimal towing altitude of 2.0$3.5 \mathrm{~m}$ above the benthic habitat. This height and the characteristics of the cameras enabled a forwardlooking field of view of 10-15 m. Transects were typically $3-8 \mathrm{~h}$ and towing depths ranged from 25$195 \mathrm{~m}$, at a near constant speed of $1.5-2.0 \mathrm{~m} \mathrm{~s}^{-1}$ with transects spanning between 20 and $70 \mathrm{~km}$ of seafloor.

\subsection{Data analysis}

All camera imagery was separated into 1 min video segments for each camera and each transect. Videos from the high-definition, black/white forward-facing camera were viewed most often (due to increased video resolution), by 1-3 individuals. Additional cameras were viewed if clarification of identification was needed (e.g. color video could aid in ID of certain fish species based on color). All fish and sea turtles were counted and identified to species when possible. For the GSPL transects, videos from the 2 sidefacing cameras were viewed in addition to the forward-facing black/white camera, since the pipe was not always in the view of the forward-facing cameras. Sea turtle species identification was determined by 2 Florida Wildlife Commission (FWC) researchers. Sea turtle sightings were characterized into 3 categories: (1) confident of species ID, (2) confident it is a turtle but not of species, and (3) possible it is a turtle but not confident. Data recorded per sighting were date/time, GPS location, species identification, sex (when able to identify), habitat, behavior, depth, temperature, salinity, and chl a concentration.

Though the C-BASS does have 2 parallel highdefinition cameras for facilitating 3D stereo measurements, this capability was undergoing development for a majority of the timeframe in which the data presented here span. For individuals sighted next to the GSPL, rudimentary measurements could be made, as this structure has a known fixed diameter of 36 inches $(0.91 \mathrm{~m})$ in the offshore regions of its extent (Federal Energy Regulatory Commission 2001) where all of the C-BASS transects occurred. Approximate sea turtle size could therefore be estimated by calculating the ratio of the pipe diameter to the standard straight carapace length $\left(\mathrm{SCL}_{\text {; }}\right.$ from the nuchal notch to the posterior marginal tip). For observations made after 2017, stereo measurement capabilities were possible but not ideal, due to syncing issues between the cameras which introduced error into stereo measurements. Estimates of length using these data could still be assessed using SeaGIS's software, EventMeasure, by taking several measurements for one individual then averaging these values to get an approximate SCL. Each sea turtle measurement was binned by size category according to the life history stages presented by Eaton et al. (2008).

Video of sea turtle benthic habitat was characterized using an abiotic habitat classification scheme based on NOAA's Coastal and Marine Ecological Classification Standard (CMECS; FGDC 2012). If needed, a combination of the multibeam bathymetry and backscatter maps along with the C-BASS observations can be used to classify all of the CMECS components (geoform, substrate, biotic, and water column) at varying degrees. The structural (natural or anthropogenic), induration (hard or soft), and primary substrate features of the benthic habitat were classified. The primary habitat substrate where the sea turtle was observed was characterized as (1) pipeline, (2) artificial reef, (3) rock outcrop, (4) ledge, or (5) sand. The pipe itself was categorized into 1 of 3 descriptive features: (1) bare (pipe fully lying on top of the seafloor without dredge or spoils), (2) buried (pipe partially or fully covered by sand and or organic detritus), or (3) dredge (rocks or spoils placed to either side of the pipe where it had to be dredged and then placed) (see Fig. 3).

Sea turtle behaviors exhibited by the observed individuals were characterized. Analyses included only the initial behavior observed per individual and behaviors were assigned to 1 of 6 categories: resting, foraging, crawling, swimming, surfacing, or diving. Resting consisted of the head, body and flippers lowered onto the benthic substrate. Foraging was defined by head movement or digging with the forelimbs within the benthic substrate. Crawling was characterized as movement along the benthic substrate while maintaining flipper or body contact with the sea bed. Swimming included movement of the flippers within the water column, only with horizontal, near-bottom locomotion. Surfacing and diving included movement of the sea turtle in a vertical direction. 
Sea turtle population density along the GSPL was estimated by survey month using a line transect sampling method. This method relies on 4 significant assumptions: first, it assumes all animals on the transect line are observed; secondly, it assumes animals are fixed at the initial sighting position; third, that the distances and angles are measured exactly; and lastly, that sightings are independent events. The estimated population density $(\hat{D})$ was then calculated using the general formula (Buckland et. al 2001):

$$
\hat{D}=\frac{n}{2 L a}
$$

where $n$ is the number of sea turtles observed on the transect, $L$ is the total length of transect and $a$ is half the effective strip width (constant). The constant $a$ estimates how wide the strip width would be if every turtle were seen and counted. Conventional distance sampling (CDS) analyses were performed using the transect length and the perpendicular sighting distances in the distance sampling program DISTANCE v.7.3 (Thomas et al. 2010).

\section{RESULTS}

A total of 9 C-BASS survey cruises were conducted from 2014 to 2018; cruises occurred during the months of February, April, May, July, and October. During these cruises a total of 97 transects $(2750 \mathrm{~km})$ were surveyed which included $1152 \mathrm{~km}$ in FMG, $777 \mathrm{~km}$ in the EL, $440 \mathrm{~km}$ on the GSPL, $199 \mathrm{~km}$ in MS, and $182 \mathrm{~km}$ in SL. Table 1 details the cruises by date, area surveyed, number of transects, distance surveyed, and number of sea turtles observed. Over $380 \mathrm{~h}$ of video and environmental sensor data were collected. C-BASS transects were piloted during day and night hours, with $81 \%$ during the day and $19 \%$ at night (19:00-07:00 h).

\subsection{Sea turtle sightings}

A total of 79 sea turtles were sighted: 69 loggerheads, 4 Kemp's ridleys, 1 green turtle, 5 hardshelled turtles that were unidentifiable to species, and 1 possible turtle, but not confident (Fig. 2). Most sea turtles $(91 \%)$ were observed on the GSPL, where a total of 70 turtles were sighted: 63 loggerheads, 3 Kemp's ridleys, 3 unidentified hard-shelled turtles, and 1 possible turtle. Several sea turtles $(n=6)$ were observed in the FMG: 4 loggerheads, 1 Kemp's ridley, and 1 green turtle. Two sea turtles were ob-
Table 1. Camera-based assessment survey system data analyzed for sea turtle observations in each area. FMG: Florida Middle Grounds; MS: Madison-Swanson; SL: Steamboat Lumps; GSPL: Gulfstream natural gas pipeline; EL: Elbow

\begin{tabular}{|c|c|c|c|c|c|}
\hline $\begin{array}{l}\text { Cruise } \\
\text { No. }\end{array}$ & $\begin{array}{c}\text { Date } \\
\text { (mm/yyyy) }\end{array}$ & $\begin{array}{c}\text { Area } \\
\text { surveyed }\end{array}$ & $\begin{array}{l}\text { No. of } \\
\text { transects }\end{array}$ & $\begin{array}{c}\text { Distance } \\
(\mathrm{km})\end{array}$ & $\begin{array}{l}\text { No. of } \\
\text { turtles }\end{array}$ \\
\hline \multirow[t]{3}{*}{1} & $05 / 2014$ & FMG & 6 & 140 & 1 \\
\hline & & MS & 2 & 41 & 0 \\
\hline & & $\mathrm{SL}$ & 2 & 64 & 0 \\
\hline \multirow[t]{3}{*}{2} & $02 / 2016$ & GSPL & 3 & 125 & 40 \\
\hline & & EL & 7 & 208 & 1 \\
\hline & & SL & 2 & 91 & 0 \\
\hline 3 & $04 / 2016$ & MS & 4 & 158 & 0 \\
\hline \multirow[t]{3}{*}{4} & $10 / 2016$ & GSPL & 1 & 68 & 10 \\
\hline & & FMG & 6 & 299 & 2 \\
\hline & & EL & 2 & 52 & 0 \\
\hline \multirow[t]{4}{*}{5} & $04 / 2017$ & GSPL & 2 & 78 & 13 \\
\hline & & FMG & 6 & 195 & 1 \\
\hline & & EL & 9 & 172 & 0 \\
\hline & & SL & 1 & 27 & 0 \\
\hline \multirow[t]{3}{*}{6} & $10 / 2017$ & GSPL & 2 & 44 & 1 \\
\hline & & FMG & 16 & 303 & 1 \\
\hline & & EL & 2 & 16 & 0 \\
\hline \multirow[t]{2}{*}{7} & $04 / 2018$ & GSPL & 1 & 58 & 1 \\
\hline & & EL & 12 & 221 & 1 \\
\hline 8 & 07/2018 & GSPL & 1 & 67 & 5 \\
\hline \multirow[t]{2}{*}{9} & 09/2018 & FMG & 6 & 215 & 2 \\
\hline & & EL & 4 & 108 & 0 \\
\hline Total & & & 97 & 2750 & 79 \\
\hline
\end{tabular}

served in the EL and they were both identified as loggerheads. No sea turtles were observed in the MS or SL MPA areas during the surveys. Two of the GSPL loggerheads were identified as males based on the tail appearing to extend well beyond the posterior edge of the carapace (approx. $>10 \mathrm{~cm}$ ). Sea turtles were observed within the benthic habitat during both day and night hours; 24 (30\%) sea turtles were observed during night hours. Most were utilizing the GSPL $(n=22)$ and were loggerheads, although 2 could not be identified to species. Two were observed in the FMG and were identified as a green turtle and a loggerhead.

\subsection{Life stage estimation}

For the 2016 sightings, stereo vision had not yet been properly calibrated, but measurements could be made for 16 sea turtles using the ratio of pipeline width to SCL; all were identified as Caretta caretta. For the 2017 and 2018 observations, an additional 5 measurements were made using the stereo-vision 

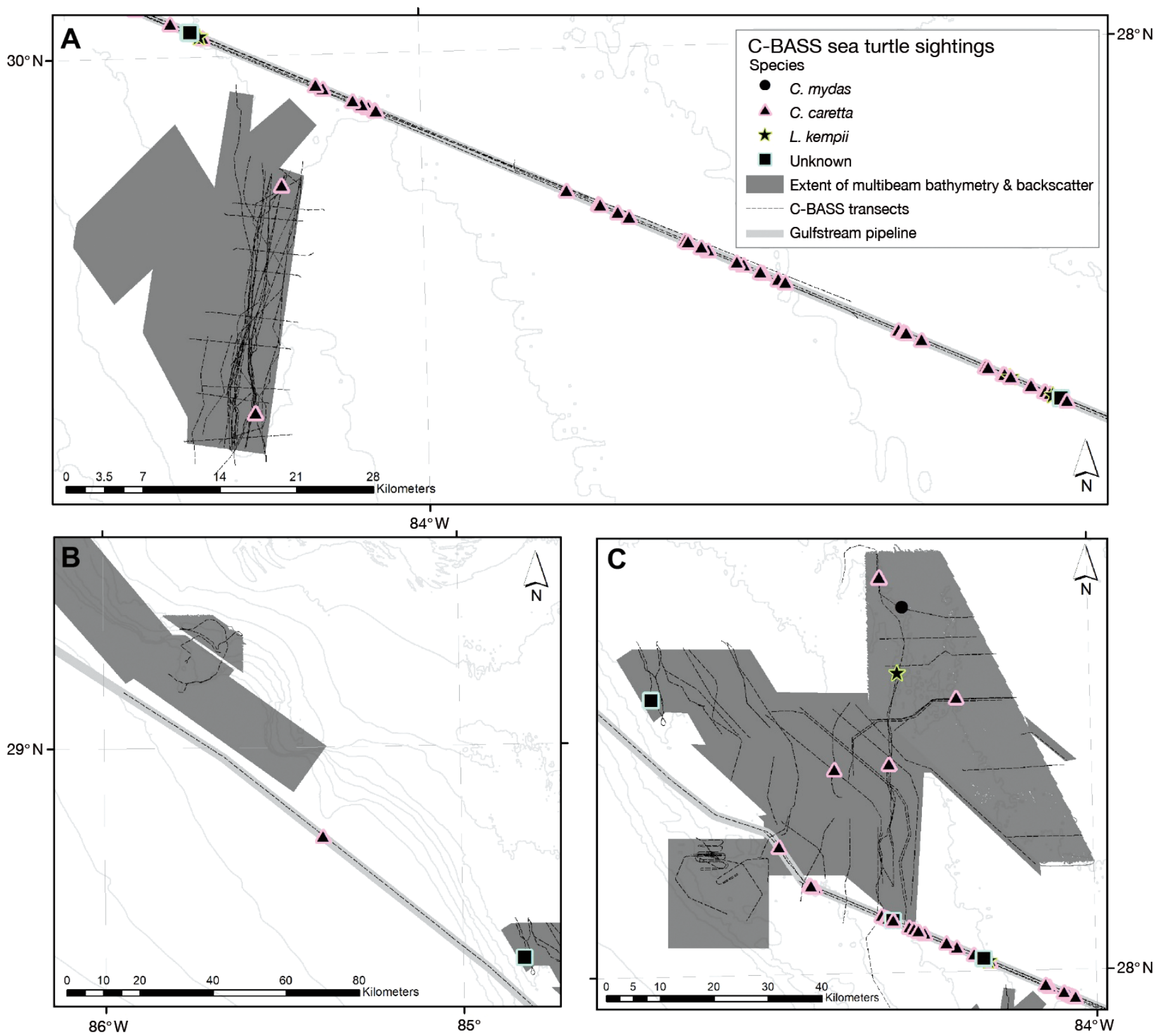

Fig. 2. Area maps of the observed sea turtles along with multibeam bathymetry (gray polygons) and the camera-based assessment survey system (C-BASS) transects completed in those years (dashed lines). (A) the Elbow and southern Gulfstream natural gas pipeline (GSPL); (B) Madison-Swanson and northern GSPL; (C) Florida Middle Grounds and central GSPL

software, EventMeasure, and all of these were identified as C. caretta. For 3 of these observations, the angle at which the turtles were observed along the SCL orientation was not conducive to accurate measurement, but standard carapace width (SCW) measurements were possible. An approach used to relate SCW to SCL is described in Marn et al. (2015) for C. caretta in the Western Atlantic, and this was used to obtain an estimate of SCL for these individuals. A majority of the measurements came from sea turtles spotted along the GSPL ( $=19$ ); only 2 individuals that resided on natural features could be measured. We grouped loggerheads into life stages based on the following breaks (Eaton et al. 2008): oceanic-stage juvenile $(<30 \mathrm{~cm})$, neritic-stage juvenile $(30-69 \mathrm{~cm})$, sub-adult $(70-79 \mathrm{~cm})$, and adult $(\geq 80 \mathrm{~cm})$. Based on the length analysis for these 21 loggerheads, the CBASS was able to observe individuals from all 4 life stages (oceanic-stage juvenile, neritic-stage juvenile, sub-adult, adult) within anthropogenic and natural habitats (Table 2). The most frequently observed life stage was neritic-stage juveniles $(n=15)$. 
Table 2. Number of loggerhead sea turtles Caretta caretta observed within each life stage category based on approximate measurements attained via camera-based assessment survey system imagery. Life stage ranges based on Eaton et al. (2008): ocean-stage juvenile: $<30 \mathrm{~cm}$; neritic-stage juvenile: 30-69 cm; sub-adult: 70-79 cm; adult: $\geq 80 \mathrm{~cm}$. GSPL: Gulfstream natural gas pipeline; FMG: Florida Middle Grounds

\begin{tabular}{|c|c|c|c|}
\hline $\begin{array}{l}\text { Loggerhead } \\
\text { life stage }\end{array}$ & Area & $\begin{array}{l}\text { Observed size } \\
\text { ranges }(\mathrm{cm})\end{array}$ & $\begin{array}{l}\text { No. of } \\
\text { turtles }\end{array}$ \\
\hline Oceanic-stage juvenile & GSPL & 29 & 1 \\
\hline Neritic-stage juvenile & & $30-67$ & 14 \\
\hline Sub-adult & & $75-78$ & 4 \\
\hline Neritic-stage juvenile & FMG & 64 & 1 \\
\hline Adult & & 92 & 1 \\
\hline
\end{tabular}

\subsection{Habitat characterization}

Sea turtles were observed in both natural and anthropogenic benthic habitats (Fig. 3). The majority of the turtles observed were found adjacent to or near an anthropogenic structure (n = 71), mainly the GSPL $(\mathrm{n}=70)$. The most utilized benthic substrate was pipe with dredge $(n=35)$, with 23 seen near bare pipe and 12 observed where the pipe was buried. One turtle in the EL was sighted near an unknown anthropogenic structure which consisted of metal debris. Only 9 sea turtles were observed in a natural benthic habitat including both hard and soft substrates which consisted of rock outcrops $(\mathrm{n}=4)$, sand $(\mathrm{n}=$ $3)$, and a ledge $(\mathrm{n}=1)$ (Table 3$)$.

Loggerheads $(\mathrm{n}=69)$ were observed utilizing all the benthic habitats and most were seen using the pipe-dredge substrate ( $\mathrm{n}=32$ ), followed by pipe-bare ( $\mathrm{n}=22$ ) and then pipe-buried $(n=9)$. A total of 5 loggerheads were observed in natural benthic habitat (rock outcrop, $\mathrm{n}=2$; sand, $\mathrm{n}=2$ ), and another loggerhead was seen utilizing a ledge. The Kemp's ridleys were observed utilizing the pipe-dredge $(n=2)$ and pipe-buried $(\mathrm{n}=1)$ along with a natural rock outcrop substrate $(\mathrm{n}=1)$. The one green turtle sighted was using a natural habitat with a rock outcrop substrate.

\subsection{Behavior analysis}

Of the 79 observed sea turtles, 58 were classified as resting, 12 were swimming, and 6 were seen crawling (Table 4). Of the 24 sea turtles observed during night hours, 23 were classified as resting and 1 was seen swimming. Loggerheads were observed exhibiting all 6 of the classified behaviors, including surfacing and diving; some of these activities were conducted within the water column and were observed when C-BASS
Fig. 3. Turtles observed on the different benthic habitat substrates: (A) Caretta caretta on natural ledge; (B) Lepidochelys kempii on natural rock outcrop; (C) $C$. caretta on natural sand; (D) C. caretta on pipe-bare; (E) C. caretta on pipe-dredge;

(F) C. caretta on pipe-buried 
Table 3. Benthic habitat (type, induration, substrate) for observed sea turtles on the West Florida Shelf during 20142018. CC: Caretta caretta; LK: Lepidochelys kempii; CM: Chelonia mydas; sp: unidentified species

\begin{tabular}{|c|c|c|c|c|}
\hline $\begin{array}{l}\text { Habitat } \\
\text { type }\end{array}$ & Induration & $\begin{array}{l}\text { Benthic } \\
\text { substrate }\end{array}$ & $\begin{array}{c}\text { Turtle } \\
\text { sp. }\end{array}$ & $\begin{array}{c}\text { No. of } \\
\text { sightings }\end{array}$ \\
\hline \multirow[t]{4}{*}{$\begin{array}{l}\text { Anthro- } \\
\text { pogenic }\end{array}$} & \multirow[t]{3}{*}{ Pipeline } & Dredge & $\begin{array}{c}\text { CC } \\
\text { LK } \\
\text { sp }\end{array}$ & $\begin{array}{c}32 \\
2 \\
1\end{array}$ \\
\hline & & Bare & $\begin{array}{l}\text { CC } \\
\text { sp }\end{array}$ & $\begin{array}{c}22 \\
1\end{array}$ \\
\hline & & Buried & $\begin{array}{l}\text { CC } \\
\text { LK } \\
\text { sp }\end{array}$ & $\begin{array}{l}9 \\
1 \\
2\end{array}$ \\
\hline & Artificial reef & Metal debris & $\mathrm{CC}$ & 1 \\
\hline \multirow[t]{3}{*}{ Natural } & Hard & Rock outcrop & $\begin{array}{c}\text { CC } \\
\text { LK } \\
\text { CM }\end{array}$ & $\begin{array}{l}2 \\
1 \\
1\end{array}$ \\
\hline & & Ledge & $\mathrm{CC}$ & 1 \\
\hline & Soft & Sand & $\begin{array}{l}\mathrm{CC} \\
\mathrm{sp}\end{array}$ & $\begin{array}{l}2 \\
1\end{array}$ \\
\hline
\end{tabular}

was either ascending or descending during deployment. Three of the Kemp's ridleys were seen resting on the seafloor and the other one was crawling along the bottom. The green turtle observed was seen swimming along the seafloor during night hours.

\subsection{In situ environmental data}

The benthic environmental data analyzed consisted of depth, temperature, salinity, and chl a recorded within an average of $4.1 \mathrm{~m}$ above the observed sea turtles (Fig. 4). The shallowest depth observed was the diving loggerhead in the water column at $26 \mathrm{~m}$, the deepest was a loggerhead at $108 \mathrm{~m}$, and the average depth was $50 \mathrm{~m}$. The majority of the sea turtles $(n=71)$ were observed between 30 and $79 \mathrm{~m}$ depth (Fig. 4A). Kemp's ridleys were observed within a depth range of 31-52 $\mathrm{m}$ and the green turtle was at $28 \mathrm{~m}$. Observed in situ water temperatures ranged from 17.1 to $28.9^{\circ} \mathrm{C}$, with the majority of the sea turtles $(\mathrm{n}=75)$ observed between 17 and $25^{\circ} \mathrm{C}$ (Fig. 4B). Salinity measurements ranged from 35.7 to 36.7 with an average of 36.4 , with the majority of the turtles $(\mathrm{n}=30)$ at 36.4 (Fig. 4C). The in situ chl a range of the observed turtles was 0.05-1.84 $\mathrm{\mu g} \mathrm{l}^{-1}$ with an average of $0.50 \mathrm{\mu g} \mathrm{l}^{-1}$. The majority of sea turtles $(n=63)$ were observed within chl a concentrations of $0.2-0.6 \mu \mathrm{g} \mathrm{l}^{-1}$ (Fig. 4D).
Table 4. Summary of sea turtle behavior for each sighting based on habitat type and species. CC: Caretta caretta ; LK: Lepidochelys kempii; CM: Chelonia mydas; sp: unidentified species

\begin{tabular}{|c|c|c|c|}
\hline Behavior & Habitat type & $\begin{array}{c}\text { Turtle } \\
\text { sp. }\end{array}$ & $\begin{array}{c}\text { No. of } \\
\text { sightings }\end{array}$ \\
\hline \multirow[t]{4}{*}{ Resting } & Anthropogenic & $\mathrm{CC}$ & 49 \\
\hline & & LK & 3 \\
\hline & & $\mathrm{sp}$ & 3 \\
\hline & Natural & $\mathrm{CC}$ & 3 \\
\hline \multirow[t]{5}{*}{ Swimming } & Anthropogenic & $\mathrm{CC}$ & 8 \\
\hline & & $\mathrm{sp}$ & 1 \\
\hline & Natural & $\mathrm{CC}$ & 1 \\
\hline & & $\mathrm{CM}$ & 1 \\
\hline & & $\mathrm{sp}$ & 1 \\
\hline \multirow[t]{2}{*}{ Crawling } & Anthropogenic & $\mathrm{CC}$ & 5 \\
\hline & Natural & LK & 1 \\
\hline Foraging & Natural & $\mathrm{CC}$ & 1 \\
\hline Diving & Anthropogenic & $\mathrm{CC}$ & 1 \\
\hline Surfacing & Anthropogenic & $\mathrm{CC}$ & 1 \\
\hline
\end{tabular}

A $46 \mathrm{~km}$ section $\left(27.91956-28.07787^{\circ} \mathrm{N}\right)$ of the pipeline was surveyed 4 separate times during the study, during the months of February, April, July, and October. Benthic temperature, salinity, and chl a were analyzed for changes (Fig. 5). The benthic temperature ranges recorded per month were 17.1$19.4^{\circ} \mathrm{C}$ (February), $20.8-20.9^{\circ} \mathrm{C}$ (April), $22.4-23.1^{\circ} \mathrm{C}$ (July), and $23.4-24.8^{\circ} \mathrm{C}$ (October). The overall benthic salinity range recorded for this section was 36.336.7, with February/April having an average salinity of 36.4 and July/October an average of 36.6. Overall

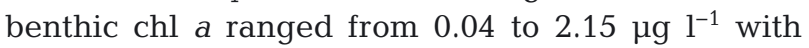
average concentrations of $0.44 \mu \mathrm{g} \mathrm{l}^{-1}$ (February), $0.96 \mu \mathrm{g} \mathrm{l}^{-1}$ (April), $0.62 \mu \mathrm{g} \mathrm{l}^{-1}$ (July), and $1.11 \mu \mathrm{g} \mathrm{l^{-1 }}$ (October). A total of 20 sea turtles were observed within the sub-section of the GSPL (Fig. 5); 17 loggerheads, $1 \mathrm{Kemp}$ 's ridley, and 2 unidentified species. Eight turtles ( 7 loggerheads, 1 unknown) were observed in February, 3 loggerheads were seen in April, 4 turtles (3 loggerheads and 1 Kemp's ridley) were seen in July, and 5 loggerheads were sighted in October.

\subsection{GSPL density estimation}

A total of 70 sea turtles were observed utilizing the GSPL as benthic habitat within the $441 \mathrm{~km}$ surveyed, resulting in an overall encounter rate of 0.16 sea turtles $\mathrm{km}^{-1}$ (Table 5). Surveys were conducted during 

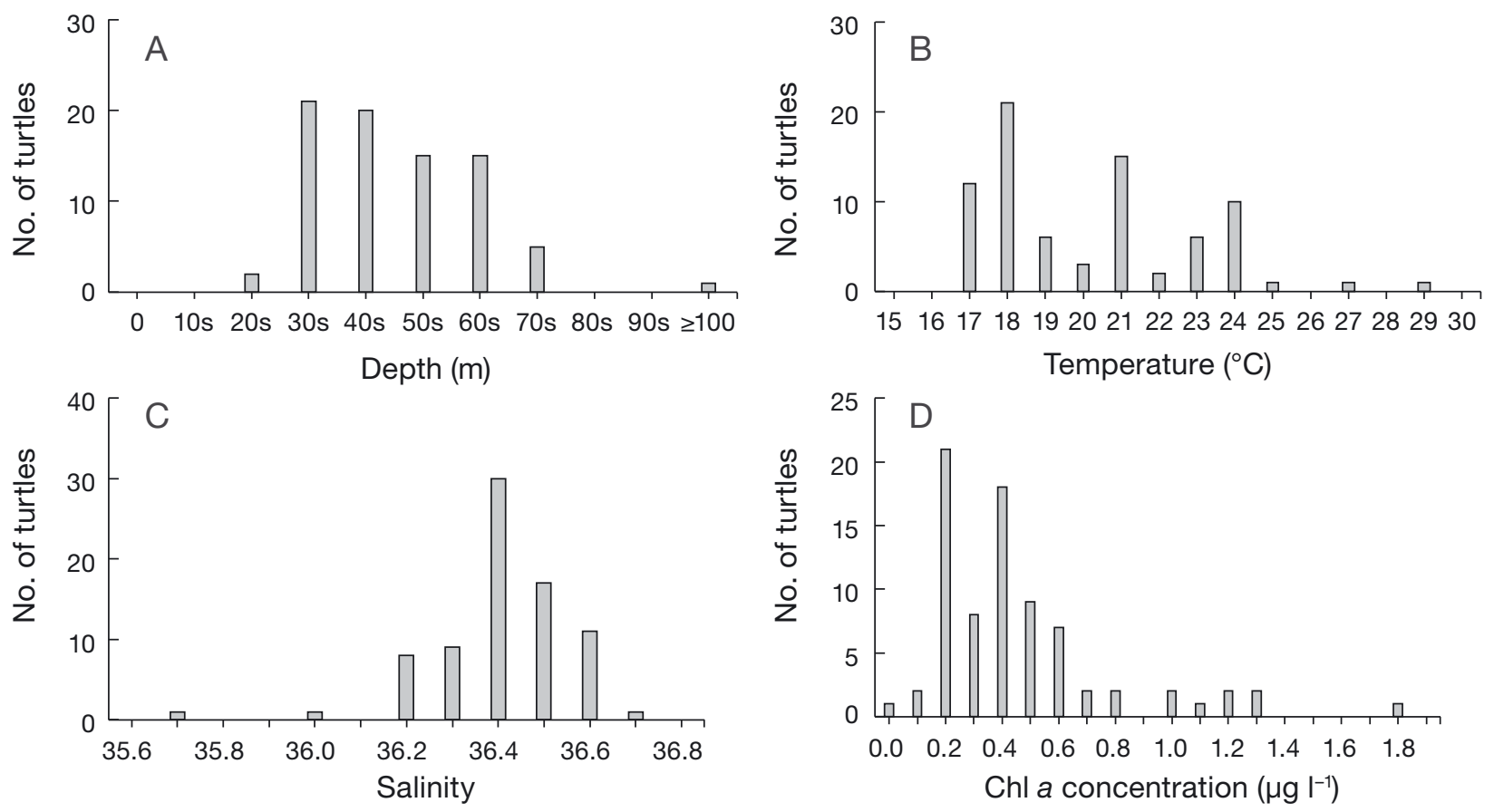

Fig. 4. Histograms showing the number of sea turtles in relation to (A) depth; (B) temperature; (C) salinity; and (D) chl a concentration

February, April, July, and October. Sea turtle density estimates were much higher in February than all the other months combined. October estimates were higher than April and July, respectively. Loggerheads were observed utilizing the GSPL during all survey months, while Kemp's were only seen during October $(\mathrm{n}=2)$ and July $(\mathrm{n}=1)$.

\section{DISCUSSION}

This study demonstrated that towed camera systems have a unique ability to document sea turtle presence over wide swaths of area in offshore ( $>25 \mathrm{~m}$ to approximately $200 \mathrm{~m}$ ) environments. In addition to recording species presence, each observed sea turtle can be evaluated for behavior, the surrounding habitat can be classified, and various environmental parameters can be measured to provide a more complete characterization of sea turtle habitat use. With the appropriate setup, these systems can also facilitate size estimates to then estimate life stage, data which are imperative to better understand sea turtle population dynamics. Though the refinement of CBASS's stereo setup was in progress during the timeframe in which these data were collected, we nonetheless demonstrated that it is possible to observe a range of life stages with this approach. In addition to collecting data on various life stages, towed camera systems such as the C-BASS offer the ability to observe sea turtle behavior. This may be of particular utility considering the need for improved data on where foraging habitats for sea turtles are located (Hamann et al. 2010).

The data from our surveys showed that the majority of the sea turtles observed were associated with a natural or artificial hard benthic substrate; either rock outcrops, ledges, metal debris, or the pipeline. Most of the sea turtles observed were associated with the GSPL, especially habitat areas of pipe with dredge material or bare pipe. Both of these pipe substrates offer substantial vertical relief and/or overhanging structure compared to the surrounding flat, sand bottom observed in the area (Fig. 6), thus providing beneficial habitat for loggerheads and Kemp's ridleys. Therefore, our data indicate that an anthropogenic pipeline structure on the WFS - the GSPL - serves as habitat for Threatened and Endangered sea turtles in the GoM. Sea turtles have long been known to use natural and artificial reefs (Stoneburner 1982, Witzell 1982, Steimle \& Zetlin 2000), including oil and gas platforms (Gitschlag \& Herczeg 1994). However, few studies have quantified use of these structures, particularly pipelines, by sea turtles. Observations revealed that the GSPL provides habitat for at least 2 sea turtle species: loggerheads and 

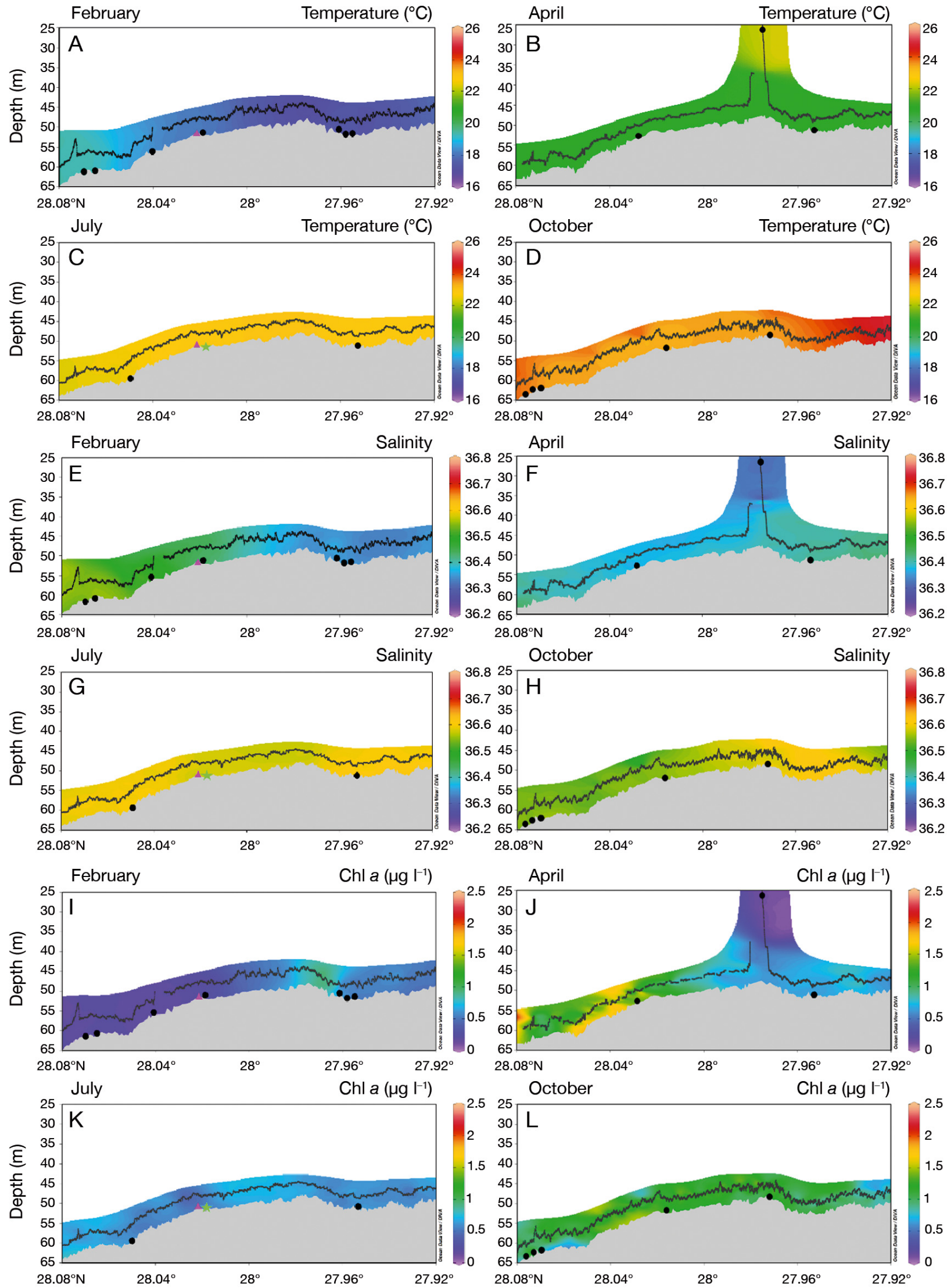

Fig. 5. Change in benthic environmental parameters along the $46 \mathrm{~km}$ Gulfstream natural gas pipeline sub-section: (A-D) temperature; (E-H) salinity; (I-L) chl a. Black line: camera-based assessment survey system track; black dots: loggerheads; green star: Kemp's ridley; pink triangles: unidentified turtle species. Plots generated using Ocean Data View software 
Table 5. Estimated sea turtle density along the Gulfstream natural gas pipeline for 6 cruises and 10 transects of the camera-based assessment survey system

\begin{tabular}{|lcccc|}
\hline Month & $\begin{array}{c}\text { Distance } \\
(\mathrm{km})\end{array}$ & $\begin{array}{c}\text { No. of turtle } \\
\text { sightings }\end{array}$ & $\begin{array}{c}\text { Encounter } \\
\text { rate }\left(\mathrm{km}^{-1}\right)\end{array}$ & $\begin{array}{c}\text { Density } \\
\left(\mathrm{km}^{-2}\right)\end{array}$ \\
\hline February & 125 & 40 & 0.32 & 73.1 \\
April & 137 & 14 & 0.10 & 12.9 \\
July & 67 & 5 & 0.07 & 5.3 \\
October & 112 & 11 & 0.10 & 27.5 \\
Overall & 441 & 70 & 0.16 & 35.5 \\
\hline
\end{tabular}

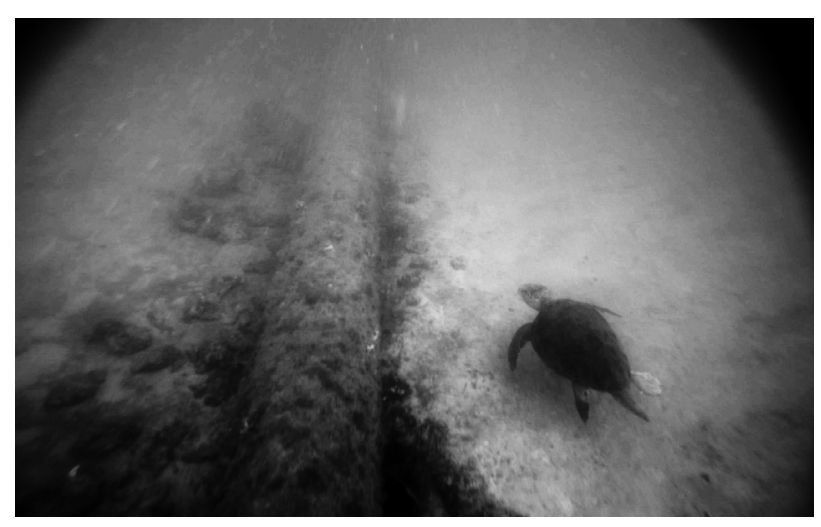

Fig. 6. Male loggerhead observed via the camera-based assessment survey system utilizing the Gulfstream pipeline. Shown is the pipe with dredge material and the flat sand substrate where the pipe was placed

Kemp's ridleys. The WFS is heavily used by these species as migratory pathways and foraging locations (Hart et al. 2014, Shaver et al. 2017) and both species have been associated with anthropogenic structures in the GoM (Rosman et al. 1987, Lohoefener et al. 1990).

The GSPL transects were only $17 \%$ of the total distance surveyed, but contained $89 \%$ of the sea turtles observed. Dupont (2008) examined fish use of artificial reefs in the area of the GSPL and found greater species richness where large boulders were placed versus similar habitat where no artificial reefs had been installed. However, our observations of disproportionate use of the GSPL by sea turtles may also be a consequence of detectability. While larger areas of other sections of the WFS (FMG and EL) were surveyed, the same section of the GSPL was examined multiple times. Since the GSPL region is a relatively flat linear area that is easy to follow and capture with the C-BASS cameras, the higher sea turtle abundance observed on the pipeline could be a function of detectability. When the water clarity was fair (approx. $5 \mathrm{~m}$ ), because of the size of the pipeline the entire potential suitable habitat was visible within the field of view of the C-BASS. Thus, detectability was likely relatively high along the pipeline compared to the natural areas. In the natural regions, the area of suitable benthic habitat was usually larger than the C-BASS field of view, thus preventing us from recording its entirety within a single transect. Also, several areas in the natural habitats were characterized by steep ridges and other topographic features that hindered the benthic viewing range of the C-BASS (e.g. pinnacles in MS MPA), thus quite possibly preventing observations of present sea turtles. Additionally, sea turtles have been known to exhibit diel behavior patterns, such as longer dives and lower activity levels during night hours (Hays et al. 2000, Christiansen et al. 2017), which suggests that sea turtles rest at depth during those hours. Most of the C-BASS transects were conducted during daylight hours, thus potentially preventing observations of benthic sea turtles due to diel activity patterns. Due to the features of the GSPL described above, it was viewed at night more than the natural areas (31 and 18\%, respectively), potentially contributing to a higher detectability of sea turtles on the pipeline.

Sea turtles may use artificial structures for foraging (Rosman et al. 1987), resting (Lohoefener et al. 1990), self-cleaning (Schofield et al. 2006), or predator avoidance (Barnette 2017). C-BASS observations discovered that most sea turtles sighted during the surveys were utilizing the GSPL as a resting area, whereas the turtles observed in the natural habitats were mostly seen performing active behaviors such as swimming, crawling, and foraging. Sea turtles use different patches within their overall home ranges for a variety of behaviors, such as foraging, resting, and breeding (Dujon et al. 2018). Movement between patches may be driven by prey availability, competition, and/or predation (Holt 1977). On the WFS, sea turtles may forage in natural habitats where prey is available and then use the GSPL as a refuge or resting site due to its extensive horizontal and vertical features.

Environmental conditions have a substantial impact on sea turtles, especially temperature. Cold in situ temperatures cause sea turtles (Caretta caretta, Lepidochelys kempii, Chelonia mydas) to stop feeding $\left(<10^{\circ} \mathrm{C}\right)$ and can result in death $\left(5-6.5^{\circ} \mathrm{C}\right)$ (Schwartz 1978), while warm temperatures $\left(27-28^{\circ} \mathrm{C}\right)$ cause shorter inter-nesting intervals in female loggerheads and green turtles (Hays et al. 2002). The in situ temperature range associated with observed sea turtles on the WFS was $17-29^{\circ} \mathrm{C}$, which is generally suitable for sea turtle physiological and behavioral activities. One green turtle and one loggerhead were observed 
during the month of October at temperatures above $27^{\circ} \mathrm{C}$, which could have affected their inter-nesting activities if they were females.

The WFS exhibits variations in circulation and sea level, which arise from changes in temperature and salinity. In this area from October to April a predominant upwelling occurs, whereas during June to September, downwelling occurs (Liu \& Weisberg 2012). Upwelling is an oceanographic process that involves wind-driven motion of dense, cooler, and usually nutrient-rich water towards the ocean surface, whereas downwelling is the process of accumulation and sinking of higher density, colder water beneath warmer or fresher water. Upwelling stimulates the growth of primary producers (chlorophyll), which could influence sea turtle habitat use (Scales et al. 2015). Chlorophyll concentration, which is an indicator of active phytoplankton biomass, has been correlated with foraging habitats and migration routes of sea turtles (Polovina et al. 2004, Kobayashi et al. 2008). Higher sea turtle density estimations for the GSPL were calculated for upwelling months (February and October) than downwelling (April and July). Also, within the $46 \mathrm{~km}$ section of the GSPL, distinct variations in benthic temperature and chl a concentrations were measured during the differing months (Fig. 5). More sea turtles were observed during upwelling months (February and October), which had the coldest and warmest average benthic temperatures and lowest and highest average benthic chl a concentrations, respectively.

Use of tracking technology has allowed researchers to identify offshore benthic hot spots for sea turtles (Walcott et al. 2012, Hardy et al. 2014, Hart et al. $2014,2018)$. However, little is known about the specific features of these habitat areas. A better understanding of the fine-scale characteristics of these features is needed so similar habitats in the GoM can be identified and conserved. Loggerheads use patches within their overall home ranges; to fully understand the environmental and habitat characteristics required for loggerhead foraging, fine-scale habitat use data are needed (Dujon et al. 2018). In the GoM, the WFS has been shown to support large numbers of sea turtles, particularly loggerheads, and factors such as bathymetry and habitat type have been suggested as drivers of this distribution (Girard et al. 2009, Foley et al. 2014, Hardy et al. 2014, 2018, Hart et al. 2018). However, this area also contains a large number of anthropogenic structures, including the GSPL, and our study is one of the first to illustrate the potential importance of this structure to sea turtles. Close associations between neritic sea turtles and benthic anthropogenic structures is not without risk. For example, anthropogenic structures pose entanglement risks (Barnette 2017) and risk of exposure to oil or chemical spills (Wallace et al. 2017). As more anthropogenic structures are installed (Dance et al. 2018), understanding how sea turtles use different artificial structures is necessary, both from the perspective of habitat requirements and injury risk. We emphasize the importance of conducting long-term studies that couple tracking technology with in situ towed instruments to better understand sea turtle benthic habitat use. Individual hotspots and the dynamics of those areas can vary from year to year due to anthropogenic, environmental, or climate changes; thus, multiple year studies are needed to capture long-term associations.

\section{CONCLUSIONS}

Characterizing the benthic habitat and developing methods to improve sub-surface sea turtle surveys is highly important to understanding sea turtle ecology. This research represents the first example of towed camera system data being used to characterize and study sea turtles in the GoM at depths greater than $30 \mathrm{~m}$ (Zawada et al. 2008). The importance of the methods and resulting data sets presented here is further underscored by how data-deficient the GoM is for sea turtles (Valverde \& Holzwart 2017). Though the C-BASS does not fill in all of the knowledge gaps that currently exist for the GoM sea turtle populations, it has demonstrated valuable utility for studying offshore occurrences of several life stages, namely for C. caretta individuals. Additionally, it does what few other types of observation platforms can, by associating an individual within a small and large-scale habitat context while also providing a description of behavior at the time of observation.

Anthropogenic structures, such as artificial reefs, oil rigs, and shipwrecks have been known to attract and support a broad range of marine wildlife, including sea turtles (Lohoefener et al. 1990, Gitschlag et al. 1997). In this study, the data showed that 2 species of sea turtles (Caretta caretta and Lepidochelys kempii) appear to frequently use the GSPL, an anthropogenic structure on the WFS. Though this is worthy of note, additional studies are needed to address whether this area is a high-use zone for turtles as foraging or resting habitat and whether it is preferential to natural hard bottom habitat in order to better understand what actual impacts this structure may be having on the Gulf's sea turtle populations. 
Acknowledgements. This work was supported by the National Fish and Wildlife Foundation's (NFWF) Gulf Environmental Benefit Fund (grant number 45892). Data from an earlier C-BASS project, the Untrawlable Habitat Survey Initiative (UHSI), were opportunistically included in the sea turtle sighting analyses; funding for that work was though NOAA's Advanced Sampling Technology Working Group (ASTWG) (grant number NA11NMF4720284). The authors thank Stanley Locker, David Naar, Alex Silverman, Steve Butcher, Gerardo Toro-Farmer, John Gray, Matthew Hommeyer, Edmund Hughes, Abigail Vivlamore, and Alex Ilich for their assistance throughout the development of this work. We also thank the crew of the R/V 'Weatherbird II' for their fieldwork leadership and assistance, as well as Simona Ceriani of Florida Fish and Wildlife Conservation Commission for classifying the species of each sea turtle observation.

\section{LITERATURE CITED}

Ballorain K, Ciccione S, Bourjea J, Grizel H, Enstipp M, Georges JY (2010) Habitat use of a multispecific seagrass meadow by green turtles Chelonia mydas at Mayotte Island. Mar Biol 157:2581-2590

Barnette MC (2017) Potential impacts of artificial reef development on sea turtle conservation in Florida. NOAA Tech Memo NMFS-SER-5

Brown CJ, Smith SJ, Lawton P, Anderson JT (2011) Benthic habitat mapping: a review of progress towards improved understanding of the spatial ecology of the seafloor using acoustic techniques. Estuar Coast Shelf Sci 92:502-520

Buckland ST, Anderson DR, Burnham KP, Laake JL, Borchers DL, Thomas L (2001) Introduction to distance sampling: estimating abundance of biological populations. Oxford University Press, Oxford

Christiansen F, Esteban N, Mortimer JA, Dujon AM, Hays GC (2017) Diel and seasonal patterns in activity and home range size of green turtles on their foraging grounds revealed by extended Fastloc-GPS tracking. Mar Biol 164:10

Nance KM, Rooker JR, Shipley JB, Dance MA, Wells RD (2018) Feeding ecology of fishes associated with artificial reefs in the northwest Gulf of Mexico. PLOS ONE 13: e0203873

Dujon AM, Schofield G, Lester RE, Papafitsoros K, Hays GC (2018) Complex movement patterns by foraging loggerhead sea turtles outside the breeding season identified using Argos linked Fastloc global positioning system. Mar Ecol 39:e12489

* Dupont JM (2008) Artificial reefs as restoration tools: a case study on the West Florida Shelf. Coast Manage 36:495-507

Eaton C, McMichael E, Witherington B, Foley A, Hardy R, Meylan A (2008) In-water sea turtle monitoring and research in Florida: review and recommendations. NOAA Tech Memo NMFS-OPR-38

Fakiris E, Blondel P, Papatheodorou G, Christodoulou D and others (2019) Multi-frequency, multi-sonar mapping of shallow habitats-efficacy and management implications in the National Marine Park of Zakynthos, Greece. Remote Sens 11:461

Fanning KA, Byrne RH, Breland JA II, Betzer PR, Moore WS, Elsinger RJ, Pyle TE (1981) Geothermal springs of the West Florida continental shelf: evidence for dolomitization and radionuclide enrichment. Earth Planet Sci Lett 52:345-354
Federal Energy Regulatory Commission (2001) Gulfstream Natural Gas System, L.L.C.; Notice of availability of the Final Environmental Impact Statement for the proposed Gulfstream Pipeline Project. Docket no. CP00-6-00. Federal Register 66:23 (February 2, 2001), p. 8783. https:// www.federalregister.gov/documents/2001/02/02/01-2834/ gulfstream-natural-gas-system-llc-notice-of-availabilityof-the-final-environmental-impact-statement

FGDC (Federal Geographic Data Committee) (2012) Coastal and marine ecological classification standard. https:// www.fgdc.gov/standards/projects/cmecs-folder/CMECS _Version_06-2012_FINAL.pdf

Foley AM, Schroeder BA, Hardy R, MacPherson SL, Nicholas M (2014) Long-term behavior at foraging sites of adult female loggerhead sea turtles (Caretta caretta) from three Florida rookeries. Mar Biol 161:1251-1262

Froeschke J, Dale D, Gulf of Mexico Fishery Management Council (2013) Fixed petroleum platforms and artificial reefs as essential fish habitat. Options paper. Generic Amendment No. 4 to Fishery Management Plans in the Gulf of Mexico. Including draft environmental impact statement, fishery impact statement, regulatory impact review, and regulatory flexibility act analysis. Gulf of Mexico Fishery Management Council, Tampa, FL. http:// gulfcouncil.org/wp-content/uploads/K-5-Artificial-Reefsas-EFH-Amendment-6-3-2013.pdf

Gallaway BJ, Lewbel GS (1982) Ecology of petroleum platforms in the northwestern Gulf of Mexico: a community profile. LGL Ecological Research Associates, Bryan, TX

Girard C, Tucker AD, Calmettes B (2009) Post-nesting migrations of loggerhead sea turtles in the Gulf of Mexico: dispersal in highly dynamic conditions. Mar Biol 156: 1827-1839

Gitschlag GR, Herczeg BA (1994) Sea turtle observations at explosive removals of energy structures. Mar Fish Rev 56:1-8

Gitschlag GR, Herczeg BA, Barcak TR (1997) Observations of sea turtles and other marine life at the explosive removal of offshore oil and gas structures in the Gulf of Mexico. Gulf Caribb Res 9:247-262

Grasty SE (2014) Use of a towed camera system for estimating reef fish populations densities on the West Florida Shelf. MSc dissertation, University of South Florida, St. Petersburg, FL

* Grasty SE, Wall CC, Gray JW, Brizzolara J, Murawski S (2019) Temporal persistence of red grouper holes and analysis of associated fish assemblages from towed camera data in the Steamboat Lumps Marine Protected Area. Trans Am Fish Soc 148:652-660

*Hamann M, Godfrey MH, Seminoff JA, Arthur K and others (2010) Global research priorities for sea turtles: informing management and conservation in the 21st century. Endang Species Res 11:245-269

*Hardy RF, Tucker AD, Foley AM, Schroeder BA, Giove RJ, Meylan AB (2014) Spatiotemporal occurrence of loggerhead turtles (Caretta caretta) on the West Florida Shelf and apparent overlap with a commercial fishery. Can J Fish Aquat Sci 71:1924-1933

Hardy RF, Hu C, Witherington B, Lapointe B and others (2018) Characterizing a sea turtle developmental habitat using Landsat observations of surface-pelagic drift communities in the eastern Gulf of Mexico. IEEE J Sel Top Appl Earth Obs Remote Sens 11:3646-3659

*Hart KM, Zawada DG, Fujisaki I, Lidz BH (2010) Inter-nesting habitat-use patterns of loggerhead sea turtles: 
enhancing satellite tracking with benthic mapping. Aquat Biol 11:77-90

Hart KM, Lamont MM, Fujisaki I, Tucker AD, Carthy RR (2012) Common coastal foraging areas for loggerheads in the Gulf of Mexico: opportunities for marine conservation. Biol Conserv 145:185-194

Hart KM, Lamont MM, Sartain AR, Fujisaki I (2014) Migration, foraging, and residency patterns for Northern Gulf loggerheads: implications of local threats and international movements. PLOS ONE 9:e103453

Hart KM, Iverson AR, Fujisaki I, Lamont MM, Bucklin D, Shaver DJ (2018) Marine threats overlap key foraging habitat for two imperiled sea turtle species in the Gulf of Mexico. Front Mar Sci 5:336

Hays GC, Adams CR, Broderick AC, Godley BJ, Lucas DJ, Metcalfe JD, Prior AA (2000) The diving behaviour of green turtles at Ascension Island. Anim Behav 59: $577-586$

Hays G, Broderick A, Glen F, Godley B, Houghton J, Metcalfe J (2002) Water temperature and internesting intervals for loggerhead (Caretta caretta) and green (Chelonia mydas) sea turtles. J Therm Biol 27:429-432

Holt RD (1977) Predation, apparent competition, and the structure of prey communities. Theor Popul Biol 12: 197-229

Hooker SK, Biuw M, McConnell BJ, Miller PJ, Sparling CE (2007) Bio-logging science: logging and relaying physical and biological data using animal-attached tags. Deep Sea Res II 54:177-182

Ilich AR (2018) Integrating towed underwater video with multibeam acoustics for mapping benthic habitat and assessing reef fish communities on the West Florida Shelf. MSc dissertation, University of South Florida, St. Petersburg, FL

Kobayashi DR, Polovina JJ, Parker DM, Kamezaki N and others (2008) Pelagic habitat characterization of loggerhead sea turtles, Caretta caretta, in the North Pacific Ocean (1997-2006): insights from satellite tag tracking and remotely sensed data. J Exp Mar Biol Ecol 356:96-114

* Lamont MM, Fujisaki I (2014) Effects of ocean temperature on nesting phenology and fecundity of the loggerhead sea turtle (Caretta caretta). J Herpetol 48:98-102

Lembke C, Grasty S, Silverman A, Broadbent H, Butcher S, Murawski S (2017) The Camera-Based Assessment Survey System (C-BASS): a towed camera platform for reef fish abundance surveys and benthic habitat characterization in the Gulf of Mexico. Cont Shelf Res 151: $62-71$

Liu Y, Weisberg RH (2012) Seasonal variability on the West Florida Shelf. Prog Oceanogr 104:80-98

Locker SD, Reed JK, Farrington S, Harter S, Hine AC, Dunn S (2016) Geology and biology of the 'Sticky Grounds', shelfmargin carbonate mounds, and mesophotic ecosystem in the eastern Gulf of Mexico. Cont Shelf Res 125:71-87

Lohoefener R, Hoggard W, Mullin K, Roden C, Rogers C (1990) Association of sea turtles with petroleum platforms in the north-central Gulf of Mexico. National Marine Fisheries Service, Pascagoula, MS

Love M, Nishimoto M, Schroeder D, Caselle J (1999) The ecological role of natural reefs and oil and gas production platforms on rocky reef fishes in southern California: final interim report. US Geological Survey, Biological Resources Division, USGS/BRD/CR-1999-007

Lutz PL, Musick JA, Wyneken J (2002) The biology of sea turtles, Vol 2. CRC Press, Boca Raton, FL
Mallinson D, Hine A, Naar D, Locker S, Donahue B (2014) New perspectives on the geology and origin of the Florida Middle Ground carbonate banks, West Florida Shelf, USA. Mar Geol 355:54-70

Marn N, Klanjscek T, Stokes L, Jusup M (2015) Size scaling in Western North Atlantic loggerhead turtles permits extrapolation between regions, but not life stages. PLOS ONE 10:e0143747

Plotkin P (1995) National Marine Fisheries Service and US Fish and Wildlife Service status reviews for sea turtles listed under the Endangered Species Act of 1973. National Marine Fisheries Service, Silver Spring, MD

* Polovina JJ, Balazs GH, Howell EA, Parker DM, Seki MP, Dutton PH (2004) Forage and migration habitat of loggerhead (Caretta caretta) and olive ridley (Lepidochelys olivacea) sea turtles in the central North Pacific Ocean. Fish Oceanogr 13:36-51

Revelles M, Camiñas JA, Cardona L, Parga M and others (2008) Tagging reveals limited exchange of immature loggerhead sea turtles (Caretta caretta) between regions in the western Mediterranean. Sci Mar 72:511-518

Rosman I, Boland G, Martin L, Chandler C (1987) Underwater sightings of sea turtles in the northern Gulf of Mexico. Final report, LGL Ecological Research Associates, Bryan, TX

* Scales KL, Miller PI, Varo-Cruz N, Hodgson DJ, Hawkes LA, Godley BJ (2015) Oceanic loggerhead turtles Caretta caretta associate with thermal fronts: evidence from the Canary Current Large Marine Ecosystem. Mar Ecol Prog Ser 519:195-207

Scarborough-Bull A, Love M, Schroeder D (2008) Artificial reefs as fishery conservation tools: contrasting the roles of offshore structures between the Gulf of Mexico and the Southern California Bight. Am Fish Soc Symp 49: 899-915

Schmid JR, Bolten AB, Bjorndal KA, Lindberg WJ, Percival HF, Zwick PD (2003) Home range and habitat use by Kemp's ridley turtles in west-central Florida. J Wildl Manag 67:196-206

Wchofield G, Katselidis KA, Dimopoulos P, Pantis JD, Hays GC (2006) Behaviour analysis of the loggerhead sea turtle Caretta caretta from direct in-water observation. Endang Species Res 2:71-79

Schwartz FJ (1978) Behavioral and tolerance responses to cold water temperatures by three species of sea turtles (Reptilia, Cheloniidae) in North Carolina. Fla Mar Res Publ 33:16-18

Seaman W Jr, Sprague LM (eds) (2013) Artificial habitats for marine and freshwater fisheries. Academic Press, San Diego, CA

Shaver DJ, Hart KM, Fujisaki I, Rubio C and others (2016) Migratory corridors of adult female Kemp's ridley turtles in the Gulf of Mexico. Biol Conserv 194:158-167

* Shaver DJ, Hart KM, Fujisaki I, Bucklin D and others (2017) Inter-nesting movements and habitat-use of adult female Kemp's ridley turtles in the Gulf of Mexico. PLOS ONE 12:e0174248

Stanley D, Wilson C (1991) Factors affecting the abundance of selected fishes near oil and gas platforms in the northern Gulf of Mexico. Fish Bull 89:149-159

Steimle FW, Zetlin C (2000) Reef habitats in the middle Atlantic bight: abundance, distribution, associated biological communities, and fishery resource use. Mar Fish Rev 62:24-42 
Stoneburner DL (1982) Satellite telemetry of loggerhead sea turtle movement in the Georgia Bight. Copeia 1982: 400-408

Thomas L, Buckland ST, Rexstad EA, Laake JL and others (2010) Distance software: design and analysis of distance sampling surveys for estimating population size. J Appl Ecol 47:5-14

USFWS and NMFS (United States Fish and Wildlife Service and National Marine Fisheries Service) (2013) Endangered and threatened wildlife and plants; designation of critical habitat for the Northwest Atlantic ocean distinct population segment of the loggerhead sea turtle (Caretta caretta). Fed Regist 78:18000-18081

Valverde RA, Holzwart KR (2017) Sea turtles of the Gulf of Mexico. In: Ward C (ed) Habitats and biota of the Gulf of Mexico: before the Deepwater Horizon oil spill, Vol 2: fish resources, fisheries, sea turtles, avian resources, marine mammals, diseases and mortalities. Springer, New York, NY, p 1189-1351

Walcott J, Eckert S, Horrocks J (2012) Tracking hawks-

Editorial responsibility: Graeme Hays,

Burwood, Victoria, Australia bill sea turtles (Eretmochelys imbricata) during internesting intervals around Barbados. Mar Biol 159: 927-938

Walcott J, Eckert S, Oxenford HA, Horrocks JA (2014) Use of a towed camera system to investigate benthic habitat use by inter-nesting female hawksbill sea turtles. Endang Species Res 24:159-170

Wallace BP, Stacy BA, Rissing M, Cacela D and others (2017) Estimating sea turtle exposures to Deepwater Horizon oil. Endang Species Res 33:51-67

* Witzell W (1982) Observations on the green sea turtle (Chelonia mydas) in Western Samoa. Copeia 1982:183-185

Zawada DG, Thompson PR, Butcher J (2008) A new towed platform for the unobtrusive surveying of benthic habitat and organisms. Rev Biol Trop 56:51-63

* Zepeda-Borja KM, Ortega-Ortiz CD, Torres-Orozco E, Olivos-Ortiz A (2017) Spatial and temporal distribution of sea turtles related to sea surface temperature and chlorophyll a in Mexican Central Pacific waters. Rev Biol Mar Oceanogr 52:375-385

Submitted: June 24, 2019; Accepted: October 30, 2019

Proofs received from author(s): January 22, 2020 